\title{
Macronutrient accumulation curves in potato genotypes in the Brazilian Savanna ${ }^{1}$
}

\author{
Gabriel Emiliano Pereira², Jackson Willian Pacheco de $\mathrm{Melo}^{2}$, Carlos Francisco Ragassi ${ }^{3}$, \\ Agnaldo Donizete Ferreira de Carvalho ${ }^{3}$, Juscimar da Silva ${ }^{3}$, Giovani Olegário da Silva ${ }^{3}$, Michelle Sousa Vilela ${ }^{2}$
}

\section{ABSTRACT}

Knowledge on the nutritional demands of different potato genotypes is necessary for the development of fertilizing recommendations. This study aimed to determine and compare the macronutrient accumulation curves in the Agata, Asterix, BRSIPR Bel and F183-08-01 potato genotypes, in order to subsidize the split fertilization that could meet the specific demands of each genotype. A randomized block design was used, with the treatments (genotypes $\times$ plant stages) arranged in a split-plot scheme, with three replications. The genotypes were grown in plots containing 75 plants each. The subplots within a plot contained four plants each and corresponded to the number of days after planting, when destructive samples of whole plants were collected. The plants from the subplots were harvested at 24, 38, 52, 66 and 80 days after planting, to estimate the dry mass accumulated by different parts of the plant (shoots + roots, tubers and whole plants), as well as to determine the macronutrient accumulation curves. F183-08-01 presented the highest total accumulation of N, Ca, Mg and S (141.37, $29.21,25.16$ and $22.36 \mathrm{~kg} \mathrm{ha}^{-1}$, respectively). The highest rates of macronutrient accumulation for all the potato genotypes occurred at 24 days after planting, coinciding with the beginning of the tubers formation.

KEYWORDS: Solanum tuberosum, nutrient uptake, split fertilization.

\section{INTRODUCTION}

Potato (Solanum tuberosum L.) is one of the most consumed vegetables worldwide and is considered an essential crop to ensure food security for the ever-increasing world population. However, in terms of profitability, the potato production in Brazil is considerably endangered by high production costs

\section{RESUMO}

Curvas de acúmulo de macronutrientes em genótipos de batata no Cerrado brasileiro

O conhecimento das demandas nutricionais dos diferentes genótipos de batata é necessário para o desenvolvimento de recomendações de fertilização. Objetivou-se determinar e comparar as curvas de acúmulo de macronutrientes nos genótipos de batata Agata, Asterix, BRSIPR Bel e F183-08-01, visando subsidiar o parcelamento de adubação que atenda as demandas específicas de cada genótipo. O delineamento foi em blocos casualizados, com os tratamentos (genótipos $\times$ estádios de planta) dispostos em esquema de parcelas subdivididas, com três repetições. Os genótipos foram cultivados em parcelas contendo 75 plantas cada. As subparcelas dentro de uma parcela continham quatro plantas cada e corresponderam ao número de dias após o plantio, quando amostras destrutivas de plantas inteiras foram coletadas. As plantas das subparcelas foram colhidas aos 24, 38, 52, 66 e 80 dias após o plantio, para estimar a massa seca acumulada por diferentes partes da planta (parte aérea + raízes, tubérculos e plantas inteiras) e para determinar as curvas de acúmulo de macronutrientes. F183-08-01 apresentou o maior acúmulo total de N, Ca, Mg e S (141,37; 29,21; 25,16; e 22,36 $\mathrm{kg} \mathrm{ha}^{-1}$, respectivamente). As maiores taxas de acúmulo de macronutrientes para todos os genótipos de batata ocorreram aos 24 dias após o plantio, coincidindo com o início da formação dos tubérculos.

PALAVRAS-CHAVE: Solanum tuberosum, absorção de nutrientes, adubação parcelada.

that can reach up to US\$ $600 \mathrm{t}^{-1}$. Fertilizers are one of the most expensive inputs for potato production, accounting for approximately $20 \%$ of the total production cost, in Brazil (Cepea 2019).

The average Brazilian potato yield is approximately $30 \mathrm{t} \mathrm{ha}^{-1}$ (IGBE 2020). Around $76-86 \%$ of its composition consist of water, the remaining being dry mas, depending on the genotype.

\footnotetext{
${ }^{1}$ Received: July 13, 2020. Accepted: Oct. 23, 2020. Published: Nov. 27, 2020. DOI: 10.1590/1983-40632020v5064416.

${ }^{2}$ Universidade de Brasília, Faculdade de Agronomia e Medicina Veterinária, Brasília, DF, Brasil.

E-mail/ORCID: gb.emiliano28@gmail.com/0000-0003-3115-9893,jwpachecco@gmail.com/0000-0001-8451-2908, michellevilelaunb@gmail.com/0000-0002-0417-568X.

${ }^{3}$ Empresa Brasileira de Pesquisa Agropecuária (Embrapa Hortaliças), Brasília, DF, Brasil.

E-mail/ORCID: carlos.ragassi@embrapa.br/0000-0003-3433-2567, agnaldo.carvalho@embrapa.br/0000-0001-5568-4874, juscimar.silva@embrapa.br/0000-0002-4082-7235, giovani.olegario@embrapa.br/0000-0002-4587-3257.
} 
Approximately $90 \%$ of the plant dry mass result from photosynthetic activity and $10 \%$ from nutrient uptake and accumulation (Fernandes et al. 2010b). Like most vegetables, potato demands a great input of macronutrients. In tropical conditions, Silva et al. (2017) showed that the higher the doses of NPK, the higher is the response and yield of a potato crop. Potato producers, in Brazil, frequently overfertilize their soils (since they do not usually test them prior to planting) with doses of macronutrients commonly exceeding $80 \mathrm{~kg} \mathrm{ha}^{-1}$ of $\mathrm{N}, 500 \mathrm{~kg} \mathrm{ha}^{-1}$ of $\mathrm{P}_{2} \mathrm{O}_{5}$ and $190 \mathrm{~kg} \mathrm{ha}^{-1}$ of $\mathrm{K}_{2} \mathrm{O}$ (Fernandes et al. 2011). An excessive use of fertilizers increases the production costs and promotes a plant nutritional imbalance, in addition to contaminating the surrounding environment (Silva et al. 2017).

Fertilizing recommendations available for the potato crop, in Brazil, are applicable to the most important (old and current) potato genotypes (Agata, Achat, Monalisa, Bintje and Macaca) planted in the traditional potato-producing regions (southeastern and southern Brazil) (Ribeiro et al. 1999). However, previous researches have already shown that the potato nutritional demands differ among genotypes and growing conditions (Fernandes et al. 2010a, Fernandes et al. 2011). Genotypes such as Mondial and Asterix extract an average of $116 \mathrm{~kg} \mathrm{ha}^{-1}$ of $\mathrm{N}$, $18 \mathrm{~kg} \mathrm{ha}^{-1}$ of $\mathrm{P}, 243 \mathrm{~kg} \mathrm{ha}^{-1}$ of $\mathrm{K}, 50 \mathrm{~kg} \mathrm{ha}^{-1}$ of Ca, $13 \mathrm{~kg} \mathrm{ha}^{-1}$ of $\mathrm{Mg}$ and $8 \mathrm{~kg} \mathrm{ha}^{-1}$ of $\mathrm{S}$, while Agata extracts $90 \mathrm{~kg} \mathrm{ha}^{-1}$ of $\mathrm{N}, 14 \mathrm{~kg} \mathrm{ha}^{-1}$ of P, $166 \mathrm{~kg} \mathrm{ha}^{-1}$ of $\mathrm{K}, 34 \mathrm{~kg} \mathrm{ha}^{-1}$ of Ca, $8 \mathrm{~kg} \mathrm{ha}^{-1}$ of $\mathrm{Mg}$ and $7 \mathrm{~kg} \mathrm{ha}^{-1}$ of $\mathrm{S}$, and their supplementation is recommended even for cultivation in highly fertile soils (Fernandes et al. 2011). This emphasizes the need of managing fertilization specifically for each genotype and producing region. Therefore, the knowledge on the nutritional demands of new and traditional genotypes growing in non-traditional regions is necessary for the development of fertilizing recommendations addressing each condition specifically.

The macronutrient accumulation progress curve indicates high-demand periods for certain nutrients, during which their supplementation must be carried out through fertilization. Split fertilization is the application of a total amount of nutrients subdivided into different applications during the crop development. It increases the use-efficiency of fertilizers, as it avoids leaching and volatilization of excessive doses applied unevenly, in relation to the crop demand (Rens et al. 2016, Ahmed et al. 2017, Silva et al. 2018). Therefore, establishing the nutrient accumulation progress curve for each genotype throughout the crop cycle may help in defining strategies for splitting the fertilization application to meet the crop demands (Fernandes et al. 2011).

Thus, this study aimed to determine and compare the macronutrient accumulation curves for the genotypes Agata, Asterix and BRSIPR Bel and the elite clone F183-08-01, under the edaphoclimatic conditions of the Federal District, Brazil, aiming to subsidize the split fertilization that could meet the specific nutrient demands of each potato genotype.

\section{MATERIAL AND METHODS}

The experiment was carried out at an experimental field (15\%55'44"S, 48.08'35"W and $1,000 \mathrm{~m}$ above the sea level), in Brasília, Federal District, Brazil. The climate of this site is classified as Aw (humid tropical with dry winter), according to the Köppen-Geiger classification. On average, the temperatures ranged from 16.2 to $27.6^{\circ} \mathrm{C}$ and the rainfall was $53 \mathrm{~mm}$ during the experimental period (Brasil 2019). The soil is classified as a Typic Hapludox with clayey texture (USDA 1999). Soil samples were collected from the $0-0.20 \mathrm{~m}$ depth layer for determining the soil chemical properties (Table 1). Liming was carried out 30 days before planting, with $1.22 \mathrm{tha}^{-1}$ of limestone, to increase the base saturation to $60 \%$. Fertilization was carried out with $120 \mathrm{~kg} \mathrm{ha}^{-1}$ of $\mathrm{N}$ applied as urea, $420 \mathrm{~kg} \mathrm{ha}^{-1}$ of $\mathrm{P}_{2} \mathrm{O}_{5}$ as single superphosphate, $240 \mathrm{~kg} \mathrm{ha}^{-1}$ of $\mathrm{K}_{2} \mathrm{O}$ as potassium chloride and $15 \mathrm{~kg} \mathrm{ha}^{-1}$ of $\mathrm{Zn}$ as zinc sulfate, in the planting furrow, following recommendations for the Brazilian Midwest (Embrapa 2016).

Table 1. Soil chemical properties (0-0.20 $\mathrm{m}$ depth layer) before the installation of the experiment.

\begin{tabular}{|c|c|c|c|c|c|c|c|c|c|}
\hline $\begin{array}{c}\mathrm{pH} \\
\mathrm{H}_{2} \mathrm{O}\end{array}$ & $\mathrm{P}$ & $\mathrm{K}^{+}$ & $\mathrm{Ca}^{2+}$ & $\mathrm{Mg}^{2+}$ & $\begin{array}{r}\mathrm{Al}^{3+} \\
\mathrm{cmol}_{\mathrm{c}} \mathrm{d}\end{array}$ & $\mathrm{H}+\mathrm{Al}$ & CEC & $\begin{array}{l}\mathrm{V} \\
\%\end{array}$ & $\begin{array}{c}\mathrm{OM} \\
\mathrm{g} \mathrm{dm}^{-3}\end{array}$ \\
\hline 5.2 & 1.0 & 46.2 & 4.6 & 0.7 & 0.0 & 6.2 & 11.7 & 47 & 33.7 \\
\hline
\end{tabular}

P-K: Mehlich-1 extractor. 
Planting was performed manually in furrows on May 15, 2018, using seed tubers standardized according to weight $(70 \mathrm{~g})$ and sprouting length $(0.5-1.0 \mathrm{~cm})$, and spaced $0.35 \mathrm{~m}$ between plants and $0.80 \mathrm{~m}$ between rows $\left(35,714\right.$ plants ha $\left.{ }^{-1}\right)$. One application of $90 \mathrm{~kg} \mathrm{ha}^{-1}$ of $\mathrm{N}$ as urea, as side dressing, was carried out entirely at the hilling time (22 days after planting - DAP).

A randomized block design was used, with treatments (genotypes $\times$ crop stages) arranged in a split-plot scheme, with three replications. The plots, including the borders, contained 75 plants each, for the Agata, Asterix, BRSIPR Bel and F183-08-01 potato genotypes. The subplots within a plot contained four plants each and corresponded to the potato crop stages $(24,38,52,66$ and $80 \mathrm{DAP})$ from which the destructive samples of whole plants were collected (Estefan et al. 2013). The sampled potato crop stages were chosen every two weeks from the hilling time to $80 \mathrm{DAP}$, when the potato leaves started their senescence process.

Sprinkling irrigation was used to maintain the soil at field capacity. The management of weeds, pests and diseases were carried out when necessary. Metribuzim $\left(0.75 \mathrm{~L} \mathrm{ha}^{-1}\right)$ was used to control weeds, clorfenapir $\left(0.25 \mathrm{~L} \mathrm{ha}^{-1}\right)$ and lambda-cyhalothrin $\left(0.18 \mathrm{~L} \mathrm{ha}^{-1}\right)$ to control Diabrotica speciosa and Lyriomiza spp., imidacloprid $\left(0.90 \mathrm{~L} \mathrm{ha}^{-1}\right)$ and tiametoxam $\left(0.18 \mathrm{~kg} \mathrm{ha}^{-1}\right)$ to control Mysus persicae and D. speciosa, and chlorotalonil $\left(0.90 \mathrm{~L} \mathrm{ha}^{-1}\right)$ to control Phythophthora infestans and Alternaria solani. Plant senescence was monitored weekly, starting at 84 DAP, and the production cycle was considered to end when $80 \%$ of the plants in each plot had died.

Four plants from each subplot were harvested at 24, 38, 52, 66 and $80 \mathrm{DAP}$, to estimate the dry mass accumulated by the different plant organs and further elaboration of the macronutrient accumulation curve. The plants were washed and separated into stems + roots, leaves and tubers. Fresh and dry masses were determined using an analytical scale (Estefan et al. 2013). Oven-dried plant organs were milled in a Wiley mill to a size of $1 \mathrm{~mm}$ (18 mesh), for further assisted microwave (Marxpress, CEM Corporation) acid solubilization $\left(\mathrm{HNO}_{3}: \mathrm{HCl} ; 4: 1 \mathrm{v} / \mathrm{v}\right)$ and determination of the $\mathrm{P}, \mathrm{K}, \mathrm{Ca}, \mathrm{Mg}$ and $\mathrm{S}$ content by inductively coupled plasma-optical emission spectroscopy (ICP/OES, Shimadzu ICPE9000, Japan). The $\mathrm{N}$ content was measured through wet digestion by the Kjeldahl method (Singh et al. 2020).
The amounts of accumulated macronutrients $\left(\mathrm{kg} \mathrm{ha}^{-1}\right)$ were estimated from the macronutrient content $\left(\mathrm{g} \mathrm{kg}^{-1}\right)$ obtained in each sample multiplied by its dry mass $\left(\mathrm{kg} \mathrm{plant}^{-1}\right)$ and plant population density (plants ha ${ }^{-1}$ ) and divided by 1,000 .

Data homogeneity was analyzed by the Levene test and residue normality by the Jarque-Bera test. Analysis of variance was carried out using the $\mathrm{F}$ test (5\%). The data obtained along the crop cycle (plants collected in the same main plot at different stages) were subjected to the sphericity test of the model to verify the effect of non-randomization of samples. Regression analyses with linear, quadratic, square root, logarithmic and mitscherlich models were performed using these samples, and the model with the highest determination coefficient $\left(\mathrm{R}^{2}\right)$ was chosen. All statistical analyses were carried out using the $\mathrm{R}$ software (R Core Team 2014).

Daily rates of macronutrient accumulation by plants were obtained by the first derivate of the adjusted regression equation made with macronutrient accumulation by plants (Fernandes et al. 2011).

\section{RESULTS AND DISCUSSION}

A significant interaction between the genotype and plant stage factors was observed in relation to the dry mass in leaves and tubers, with individual regressions being elaborated for each genotype, in relation to the plant stage, but not in relation to the dry mass in the shoots + roots, which was elaborated as a single regression based on the mean values of the genotypes (Table 2). The dry mass accumulated in the whole plant of F183-08-01 was superior to those of Agata and BRSIPR Bel and showed no significant difference from Asterix $(p=0.05)$.

Differences in the pattern of nutrient accumulation in the whole plant were observed among the genotypes. The same pattern was not observed when comparing the nutrient accumulation by tubers.

The highest macronutrient accumulation rate in the plants occurred at the beginning of the tuber formation stage, at $31 \mathrm{DAP}$, in accordance with Fernandes et al. (2011), who observed that the highest macronutrient demand in potato coincides with the beginning of the tuber formation stage. Based on this information, the side-dressing fertilization for the potato crop might be planned to release nutrients at the same pace as the nutrient uptake following the beginning of the tuber formation stage. The 
accumulation of macronutrients by the whole plant $\left(\mathrm{kg} \mathrm{ha}^{-1}\right)$ followed a descending order: $\mathrm{K}>\mathrm{N}>\mathrm{Ca}>$ $\mathrm{Mg}=\mathrm{S}>\mathrm{P}$ (Figures 1C, 2C, 3C, 4C, 5C and 6C), similarly to the accumulation order observed by Fernandes et al. (2011).
The $\mathrm{N}$ accumulation curve of shoots + roots followed a similar pattern for all genotypes, but significant differences were noticed for the values at the $\mathrm{N}$ accumulation peak, that occurred between 52 and 66 DAP (Figure 1A). The elite clone F183-08-01

Table 2. Regression equations for the amounts of dry mass accumulated in different parts of plants of four potato genotypes and dry mass in the whole plant at 80 days after planting.

\begin{tabular}{|c|c|c|c|c|}
\hline Genotypes & $\begin{array}{l}\text { Leaves } \\
\left(\mathrm{kg} \mathrm{ha}^{-1}\right)\end{array}$ & $\begin{array}{l}\text { Shoots + roots } \\
\left(\mathrm{kg} \mathrm{ha}^{-1}\right)\end{array}$ & $\begin{array}{l}\text { Tubers } \\
\left(\mathrm{kg} \mathrm{ha}^{-1}\right)\end{array}$ & $\begin{array}{c}\text { Whole plant at } \\
80 \text { DAP }\left(\mathrm{kg} \mathrm{ha}^{-1}\right)\end{array}$ \\
\hline Agata & $\begin{array}{c}\mathrm{y}=-4,702-93.43 \mathrm{x}+1,449 \mathrm{x}^{0.5} \\
\mathrm{R}^{2}=0.84 * *\end{array}$ & \multirow{4}{*}{$\begin{array}{c}\mathrm{y}=-661.7+38.74 \mathrm{x}-0.3161 \mathrm{x}^{2} \\
\mathrm{R}^{2}=0.99 * *\end{array}$} & $\begin{array}{c}\mathrm{y}=-26,771-305.6 \mathrm{x}+6,356 \mathrm{x}^{0.5} \\
\mathrm{R}^{2}=0.89 * *\end{array}$ & $7,268.27 b^{(1)}$ \\
\hline Asterix & $\begin{array}{c}\mathrm{y}=-6,569-140.8 \mathrm{x}+2,073 \mathrm{x}^{0.5} \\
\mathrm{R}^{2}=0.75^{* *}\end{array}$ & & $\begin{array}{c}\mathrm{y}=-9,320+327.7 \mathrm{x}-1.652 \mathrm{x}^{2} \\
\mathrm{R}^{2}=0.85^{* *}\end{array}$ & $8,505.19 \mathrm{ab}$ \\
\hline BRSIPR Bel & $\begin{array}{c}\mathrm{y}=-1,299+72.78 \mathrm{x}-0.584 \mathrm{x}^{2} \\
\mathrm{R}^{2}=0.93 * *\end{array}$ & & $\begin{array}{c}\mathrm{y}=-7,972+274.1 \mathrm{x}-1.253 \mathrm{x}^{2} \\
\mathrm{R}^{2}=0.85^{* *}\end{array}$ & $7,511.45 \mathrm{~b}$ \\
\hline F183-08-01 & $\begin{array}{c}\mathrm{y}=-4,781-85.33 \mathrm{x}+1,431 \mathrm{x}^{0.5} \\
\mathrm{R}^{2}=0.90 * *\end{array}$ & & $\begin{array}{c}\mathrm{y}=-31,199+8,678 \ln (\mathrm{x}) \\
\mathrm{R}^{2}=0.94^{* *}\end{array}$ & $9,494.00 \mathrm{a}$ \\
\hline
\end{tabular}

(1) Means followed by the same letter in the column did not differ $(\mathrm{p}=0.05)$.** Significant $(\mathrm{p}=0.01) . \mathrm{y}=$ accumulated dry mass $\left(\mathrm{kg}\right.$ ha $\left.{ }^{-1}\right)$; $\mathrm{x}=$ days after planting $(\mathrm{DAP})$.
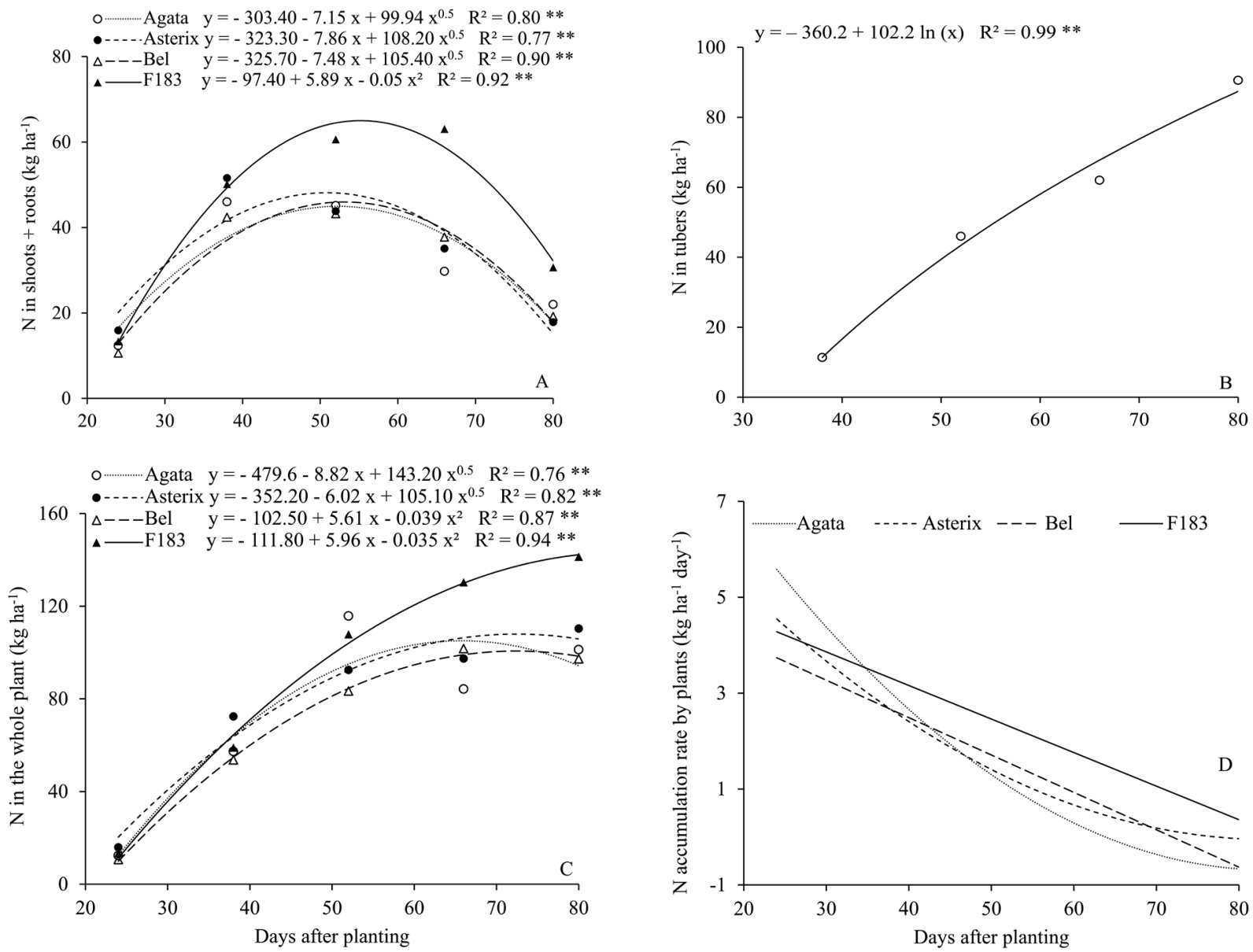

Figure 1. Nitrogen $(\mathrm{N})$ accumulation by shoots + roots (A), tubers (B) and whole plants (C), and N accumulation rate of plants (D) of three potato genotypes and one elite clone over the production cycle. 
accumulated more $\mathrm{N}$ in the shoots + roots than BRSIPR Bel and Asterix at 52 DAP, and more $\mathrm{N}$ than all the other genotypes at 66 DAP.

The total amounts of $\mathrm{N}$ accumulated by Agata and F183-08-01 plants were 101 and $142 \mathrm{~kg} \mathrm{ha}^{-1}$, respectively (Figure 1C). Agata, Asterix and BRSIPR Bel accumulated, on average, $102.94 \mathrm{~kg} \mathrm{ha}^{-1}$, similarly to the average values observed by Fernandes et al. (2011 and 2017) and Soratto \& Fernandes (2016). Among all the genotypes, F183-08-01 accumulated a considerably higher amount of $\mathrm{N}$, emphasizing the need of studying nutrient demands individually for each potato genotype. Alva et al. (2011) reported a N accumulation of over $300 \mathrm{~kg} \mathrm{ha}^{-1}$ for potato.

Agata, Asterix and BRSIPR Bel extracted slightly less $\mathrm{N}$ than the amount of $\mathrm{N}$ applied (120 kg ha-1), while F183-08-01 accumulated an additional of $22 \mathrm{~kg} \mathrm{ha}^{-1}$. This may be attributed to the better N-use efficiency of F183-08-01; however, further evaluation is warranted to explain this behavior.

According to Alva et al. (2011), 40-50\% of the total $\mathrm{N}$ is absorbed by plants during the first $40 \mathrm{DAP}$, similarly to what was observed in the present study, in which the $\mathrm{N}$ accumulated until $40 \mathrm{DAP}$ ranged 41.70-65.62\% of the total $\mathrm{N}$ absorbed (Figure 1C). On the other hand, Fernandes et al. (2011) reported that only $26 \%$ of the total $\mathrm{N}$ was absorbed by plants up to 40 DAP. These differences reflect the use of different genotypes with different productive cycles and evaluation sites, reinforcing the need to assess the nutritional demands of each genotype under different production conditions.

The tuber formation stage, as well as the $\mathrm{N}$ accumulation in tubers, started at 38 DAP. At the same time, the $\mathrm{N}$ accumulation rate in the shoots + roots decreased until it reached a maximum point of accumulation at $52 \mathrm{DAP}$, followed by a reduction in accumulated $\mathrm{N}$ from $52 \mathrm{DAP}$ to the end of the production cycle. This was due to the translocation of $\mathrm{N}$ from the leaves to the tubers, in addition to the senescence of the leaves observed after this period, as described by Alva et al. (2002) and Fernandes et al. (2011).

Fertilization programs described in the literature recommend that the largest parcel of $\mathrm{N}$ be applied at the planting time (Ribeiro et al. 1999). However, plants are unable to take up large amounts of $\mathrm{N}$ during the initial stages (i.e., during the initial DAP), what makes this nutrient susceptible to natural losses that may reach up to $49 \%$ (Weber \& Mielniczuk
2009). According to Alva et al. (2011), the application of $\mathrm{N}$ subdivided into small parts applied through irrigation water promotes a greater availability of $\mathrm{N}$ for plants and increases the absorption efficiency of this nutrient. Thus, knowing the total amount of $\mathrm{N}$ absorbed, as well as its absorption pattern, by different genotypes supports improvements in the nutritional management of a potato crop.

In view of the results obtained herein, it was possible to observe that the amounts of $\mathrm{N}$ and $\mathrm{P}$ absorbed by the studied potato genotypes (Figures 1C and 2C) were not different up to 38 DAP. Differentiation among the genotypes was observed after 52 DAP.

The total amounts of $\mathrm{N}$ absorbed by Agata and Asterix plants were 100.1 and $106.6 \mathrm{~kg} \mathrm{ha}^{-1}$, respectively. In a study by Fernandes et al. (2011), the $\mathrm{N}$ uptake by these two genotypes was 90 and $117 \mathrm{~kg} \mathrm{ha}^{-1}$, respectively. The difference between these observations may be attributed to the different edaphoclimatic conditions under which the trials were carried out (Sancho 1999), mainly the different photoperiod characteristics and temperatures that influence the duration of the production cycle.

The N, P, K, Ca and S accumulation in the tubers increased from 24 to 80 DAP, with no difference among the genotypes (Figures $1 \mathrm{~B}, 2 \mathrm{~B}, 3 \mathrm{~B}$, $4 \mathrm{~B}$ and $5 \mathrm{~B}$ ). The daily N, P, K, Ca and $\mathrm{S}$ accumulation rates in the plants showed the highest value at $24 \mathrm{DAP}$ and the lowest one at $80 \mathrm{DAP}$, for all the genotypes (Figures 1D, 2D, 3D, 4D and 5D). The amount of $\mathrm{N}$ accumulated by the whole plants (Figure 1C) was similar among all the four genotypes from 24 to 38 DAP. The highest $\mathrm{N}$ accumulation by the whole plants of Agata (observed value) occurred at 52 DAP, presenting a higher $\mathrm{N}$ accumulation rate than BRSIPR Bel, but a value similar to the other genotypes at 52 DAP. The elite clone F183-08-01 showed the highest $\mathrm{N}$ accumulation rate from 66 to $80 \mathrm{DAP}$.

The maximum amounts of $\mathrm{P}$ accumulated in the plants ranged from 7.14 to $9.70 \mathrm{~kg} \mathrm{ha}^{-1}$ for BRSIPR Bel and F183-08-01, respectively, at 80 DAP (Figure 2B). The maximum amounts of $\mathrm{P}$ extracted by Agata and Asterix plants were 9.17 and $8.47 \mathrm{~kg} \mathrm{ha}^{-1}$, respectively. Soratto \& Fernandes (2016) and Fernandes et al. (2011) observed a P absorption of 13 and $14 \mathrm{~kg} \mathrm{ha}^{-1}$ in Agata plants, respectively, and $18 \mathrm{~kg} \mathrm{ha}^{-1}$ in Asterix plants.

The amount of $\mathrm{P}$ accumulated by the whole plant (Figure 2B) was similar among the genotypes 

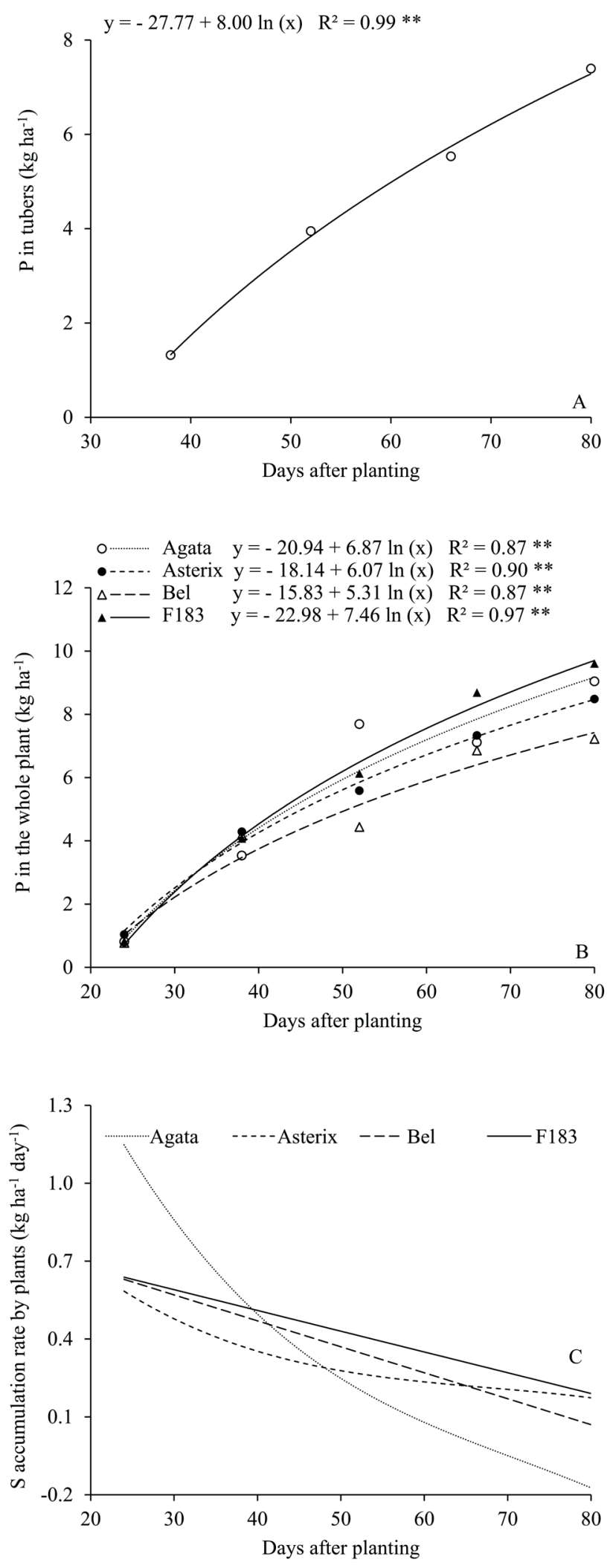

Figure 2. Phosphorus (P) accumulation by tubers (A) and whole plants (B) and $\mathrm{P}$ accumulation rate of plants (C) of three potato genotypes and one elite clone over the production cycle. over the production cycle, except at 52 DAP and 80 DAP. Agata showed the highest $\mathrm{P}$ accumulation (observed value) among the four genotypes at 52 DAP, and the elite clone F183-08-01 accumulated more $\mathrm{P}$ than BRSIPR Bel at 80 DAP.

The $\mathrm{K}$ accumulation pattern was the same for all the evaluated genotypes $(\mathrm{p}<0.01)$, concerning the shoots + roots, tubers and whole plants (Figures 3A, 3B and 3C). The same pattern was observed for the daily $\mathrm{K}$ accumulation rate of all the genotypes (Figure 3D).

The amount of $\mathrm{K}$ accumulated by plants, regardless of the studied genotype, reached a maximum of $182.8 \mathrm{~kg} \mathrm{ha}^{-1}$ in the present study, corresponding to $91.76 \%$ of the $\mathrm{K}$ applied through fertilization (199.22 $\left.\mathrm{kg} \mathrm{ha}^{-1}\right)$.

Although the amount of $\mathrm{K}$ accumulated by the plants did not vary among the evaluated genotypes, Soratto \& Fernandes (2016) also did not observe differences in the amount of $\mathrm{K}$ absorbed by the Agata and Mondial genotypes (154.51 kg ha-1) under the same fertilization treatment. However, this variation may exist, mainly when genotypes with different cycle lengths are used (Sancho 1999), as observed by Fernandes et al. (2017), who found K accumulation values ranging from 85 to $253 \mathrm{~kg} \mathrm{ha}^{-1}$, and Fernandes et al. (2011), who observed variations from 166 to $256 \mathrm{~kg} \mathrm{ha}^{-1}$, respectively for Agata and Mondial plants.

In addition, the availability of $\mathrm{P}$ in the soil interferes with the absorption of $\mathrm{K}$ by plants, as noticed in the study conducted by Fernandes et al. (2017), in which an accumulation of $\mathrm{K}$ in plants ranging from 97 to $253 \mathrm{~kg} \mathrm{ha}^{-1}$ was observed in the same potato genotype submitted to low and high $\mathrm{P}$ availability, respectively. This explains the possible differences in the accumulation of $\mathrm{K}$ in plants of the same genotype, when evaluated under different cultivation conditions, such as Asterix, which accumulated $182.8 \mathrm{~kg} \mathrm{ha}^{-1}$ of $\mathrm{K}$ in the present study and approximately $230 \mathrm{~kg} \mathrm{ha}^{-1}$ of $\mathrm{K}$ when cultivated in the city of Itaí, São Paulo state, Brazil (Fernandes et al. 2011), under conditions of high $P$ availability $\left(71 \mathrm{mg} \mathrm{dm}^{-3}\right)$. This is due to the direct relationship between $\mathrm{P}$ availability and root growth. Conditions of high $\mathrm{P}$ availability provide a greater root growth and, consequently, a greater absorption of water and nutrients (Sandaña 2016).

The $\mathrm{Ca}$ accumulation pattern in the shoots + roots was similar among the genotypes (Figure 4A), and significant differences were observed at the end of the production cycle (between 66 and 80 DAP). 

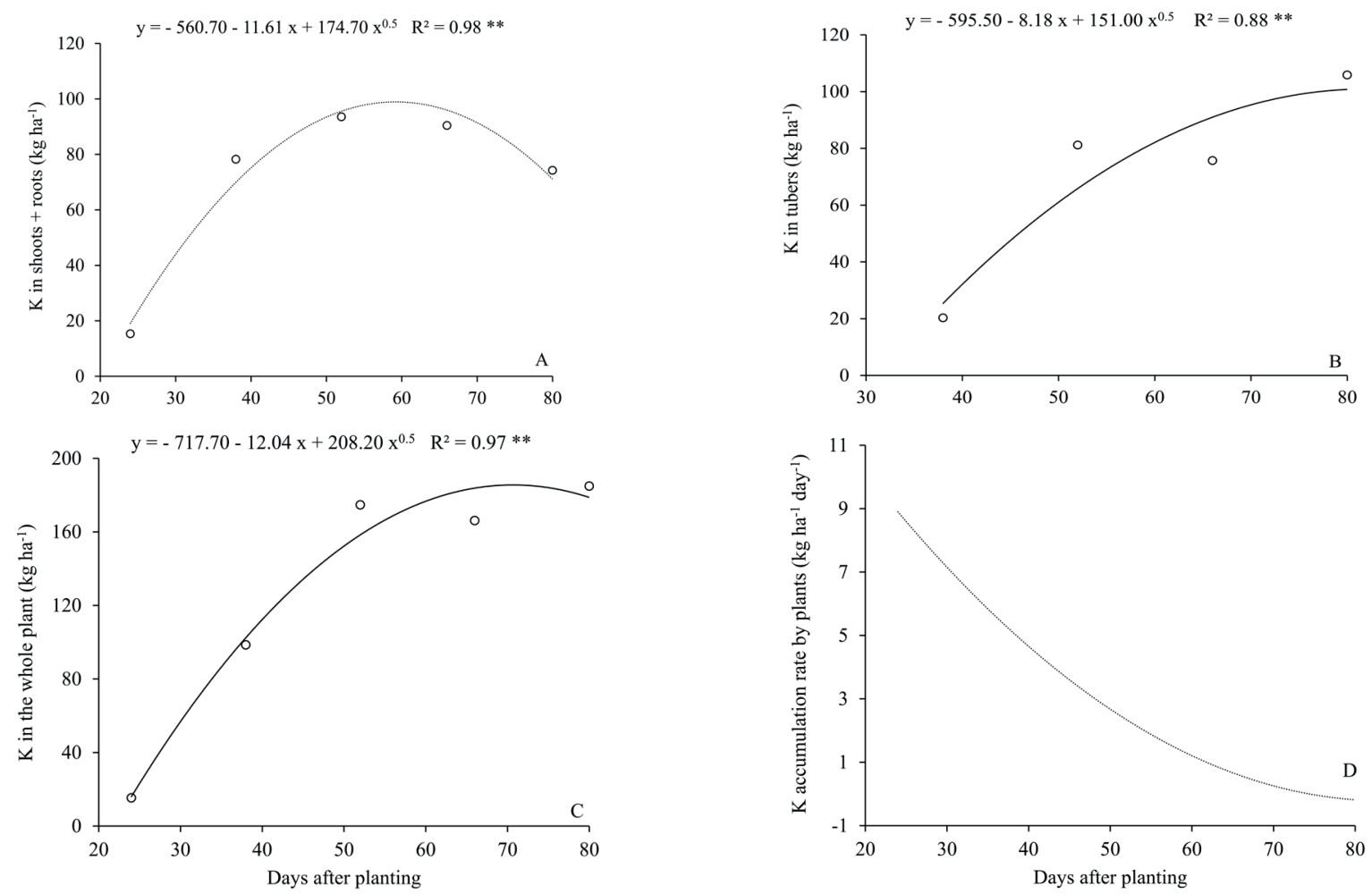

Figure 3. Potassium (K) accumulation by shoots + roots (A), tubers (B) and whole plants (C) and K accumulation rate of plants (D) of three potato genotypes and one elite clone over the production cycle.
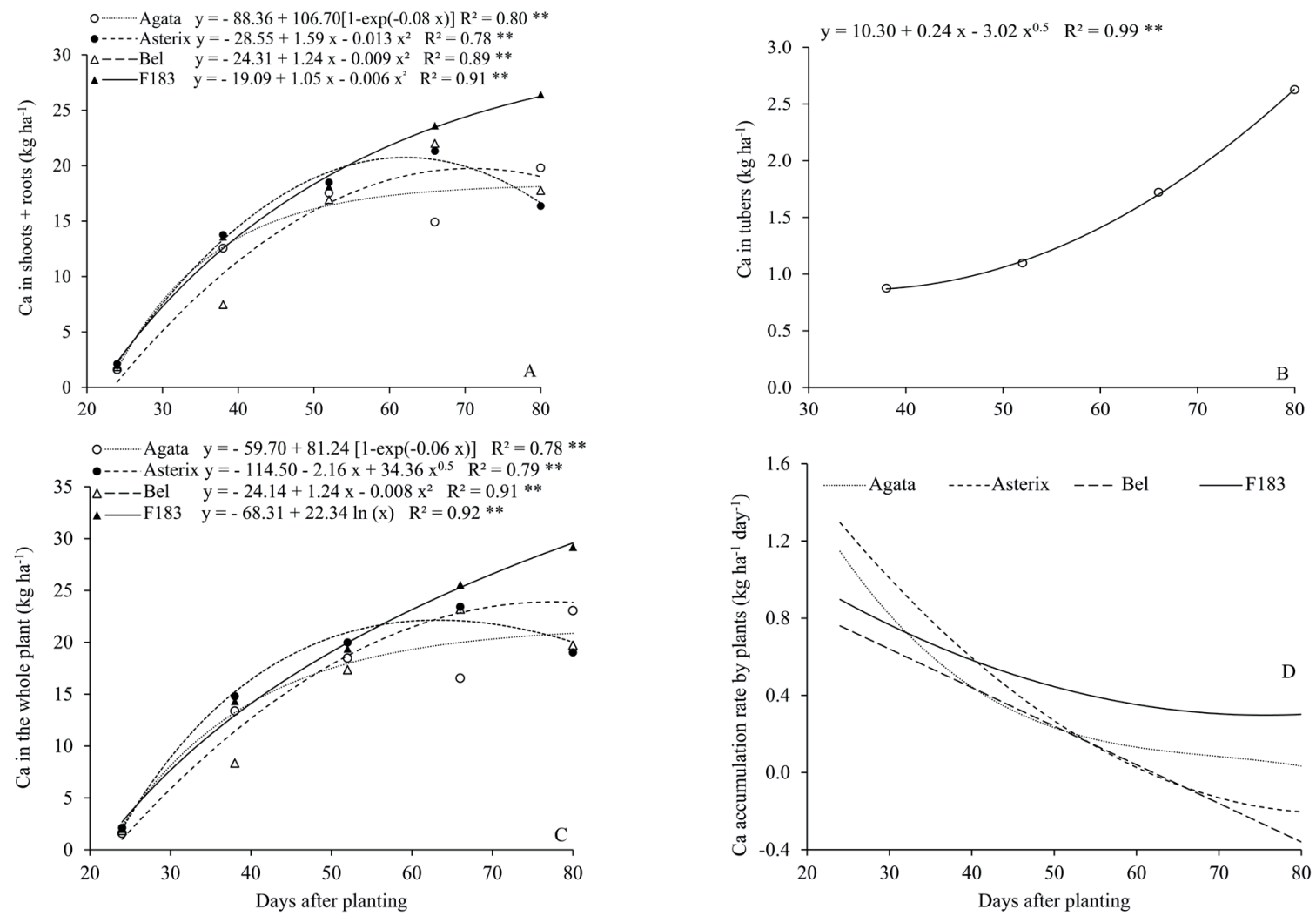

Figure 4. Calcium (Ca) accumulated by shoots + roots (A), tubers (B) and whole plants (C) and Ca accumulation rate of plants (D) of three potato genotypes and one elite clone over the production cycle. 
F183-08-01 and BRSIPR Bel accumulated more $\mathrm{Ca}$ than Agata at 66 DAP (observed values); and F183-08-01 accumulated more Ca than BRSIPR Bel and Asterix at 80 DAP (Figure 4A). The amount of $\mathrm{Ca}$ accumulated by whole plants (Figure 4C) was the same among the genotypes from 24 to 52 DAP. F183-08-01 accumulated more Ca than Agata at 66 DAP and had the highest $\mathrm{Ca}$ accumulation of all the genotypes at $80 \mathrm{DAP}$.

The amounts of $\mathrm{Ca}$ accumulated in the plants ranged from 21.54 to $29.59 \mathrm{~kg} \mathrm{ha}^{-1}$, respectively for Agata and F183-08-01. Fernandes et al. (2017) found a greater variation in $\mathrm{Ca}$ accumulation values, being 12 and $30 \mathrm{~kg} \mathrm{ha}^{-1}$ for Atlantic and Mondial, respectively. The authors verified that, under ideal growing conditions, Agata and Asterix accumulated 22 and $25 \mathrm{~kg} \mathrm{ha}^{-1}$ of $\mathrm{Ca}$, respectively, being very close to the values found in the present study $\left(22.76 \mathrm{~kg} \mathrm{ha}^{-1}\right.$ of Ca for Asterix). According to Soratto \& Fernandes (2016), Agata accumulated $20.06 \mathrm{~kg} \mathrm{ha}^{-1}$ of Ca.
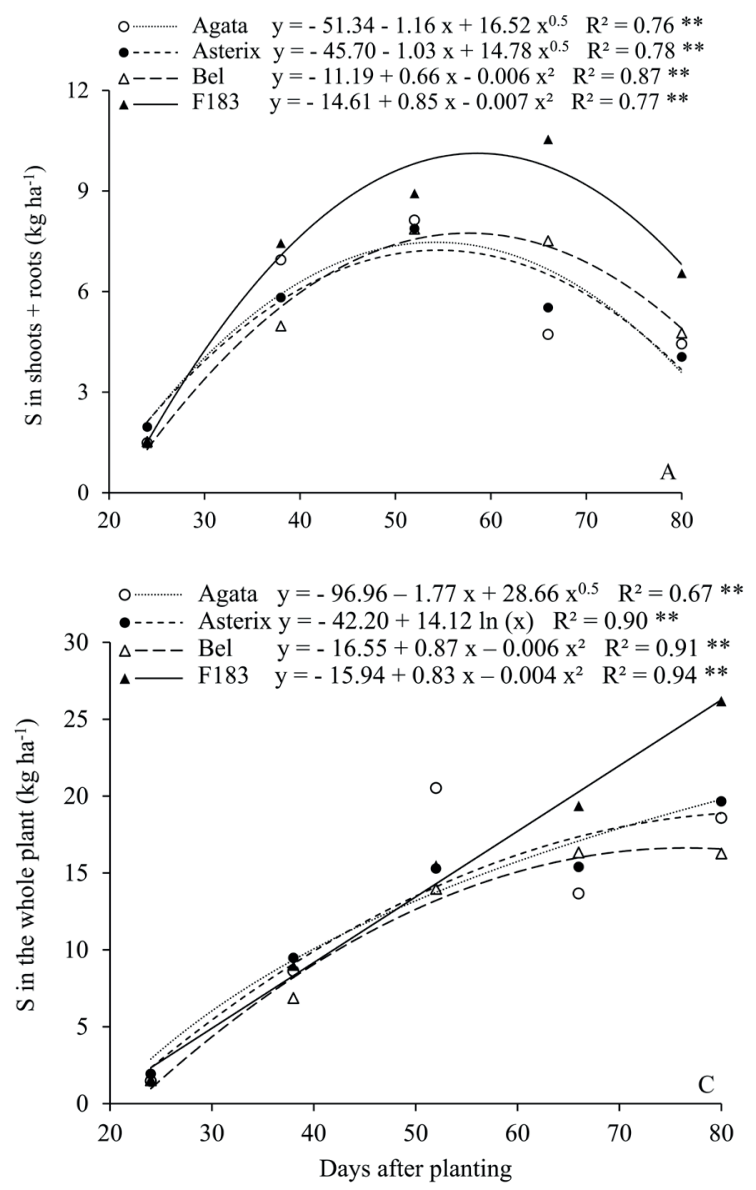

In whole plants, most of the Ca was accumulated in the shoots (85-97\% of the total $\mathrm{Ca}$ accumulated). Fernandes et al. (2011) observed that a large part of the $\mathrm{Ca}$ absorbed by plants accumulates in the shoots and is not further translocated to the tubers. The $\mathrm{Ca}$ accumulated in the tubers is absorbed by the stolon roots, reinforcing the importance of liming to increase the Ca availability to plants (Fernandes et al. 2011). Fernandes et al. (2011) observed that the amounts of $\mathrm{Ca}$ accumulated in Atlantic and Mondial plants were 33 and $51 \mathrm{~kg} \mathrm{ha}^{-1}$, respectively, while those accumulated in the leaves represented $68 \%$ and $74 \%$ of the total $\mathrm{Ca}$ extracted, respectively.

The amount of $\mathrm{S}$ accumulated by the shoots + roots was different among the genotypes at 66 DAP, when F183-08-01 showed the highest $\mathrm{S}$ accumulation, followed by BRSIPR Bel, which accumulated more $\mathrm{S}$ than Agata (Figure 5A). The amount of $\mathrm{S}$ accumulated by the whole plant (Figure 5C) was similar among the genotypes from 24 to 66 DAP.
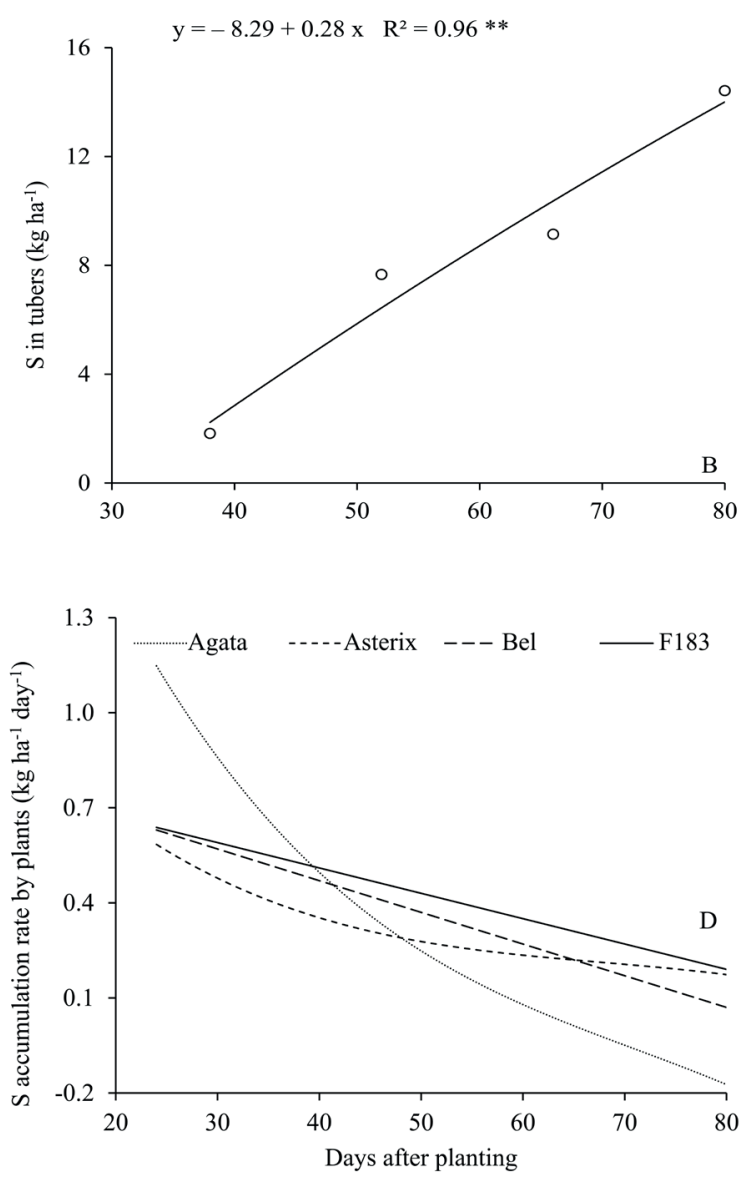

Figure 5. Sulphur (S) accumulation by shoots + roots (A), tubers (B) and whole plants (C) and S accumulation rate of plants (D) of three potato genotypes and one elite clone over the production cycle. 
F183-08-01 accumulated more $\mathrm{S}$ than all the other genotypes at $80 \mathrm{DAP}$.

The amounts of S accumulated in BRSIPR Bel and F183-08-01 plants were 16.78 and $23.19 \mathrm{~kg} \mathrm{ha}^{-1}$, respectively, and the amounts extracted by Agata and Asterix plants were also quite similar, being 19.65 and $19.69 \mathrm{~kg} \mathrm{ha}^{-1}$, respectively (Figure 5C). These values are considerably higher than those observed by Fernandes et al. (2017) and Soratto \& Fernandes (2016), in which Agata plants accumulated $7 \mathrm{~kg} \mathrm{ha}^{-1}$ of S. According to Marschner (2012), S is a highly mobile element, that can be easily translocated from the shoots to the tubers. This explains the results observed in this experiment, in which the total amount of S accumulated in the tubers was the same in all the four evaluated genotypes and represented an average of $76.89 \%$ of the total $\mathrm{S}$ accumulated in the plants (Figure 5B).

The amount of $\mathrm{Mg}$ accumulated by tubers was similar among the genotypes from 38 to 66 DAP, showing differences among all the genotypes only at 80 DAP, when F183-08-01 showed the highest accumulation (Figure 6A). The amount of $\mathrm{Mg}$ accumulated by whole plants (Figure 6B) was similar among the genotypes only at 24 DAP. F183-08-01 accumulated more Mg than BRSIPR Bel at 38 DAP (observed values). F183-08-01 and Agata accumulated more $\mathrm{Mg}$ than Asterix and BRSIPR Bel at 52 DAP (observed values). From 66 to 80 DAP, F183-08-01 accumulated more $\mathrm{Mg}$ than all the other genotypes, and Asterix accumulated more $\mathrm{Mg}$ than Agata and BRSIPR Bel.

The amounts of $\mathrm{Mg}$ accumulated in BRSIPR Bel and F183-08-01 plants were 12.54 and $26.18 \mathrm{~kg} \mathrm{ha}^{-1}$, respectively. Fernandes et al. (2011) observed an accumulation of 8 and $14 \mathrm{~kg} \mathrm{ha}^{-1}$ in Agata and Mondial plants, respectively, whereas, in the present study, the Agata plants accumulated $14.01 \mathrm{~kg} \mathrm{ha}^{-1}$ of $\mathrm{Mg}$. In a study carried out with different $\mathrm{P}$ availability conditions, Fernandes et al. (2017) found that the amounts of $\mathrm{Mg}$ accumulated in potato plants were 6 and $17 \mathrm{~kg} \mathrm{ha}^{-1}$ for low and high $\mathrm{P}$ availability conditions, respectively.

The nutrient accumulation rate of plants indicates the daily amount of nutrients demanded by each genotype (Figures 1D, 2C, 3D, 4D, 5D and $6 \mathrm{C})$. The fertilizer application to meet this nutrient demand must take into account the release rate of each source of fertilizer; that is, if a given source of nutrient takes two weeks to be available for
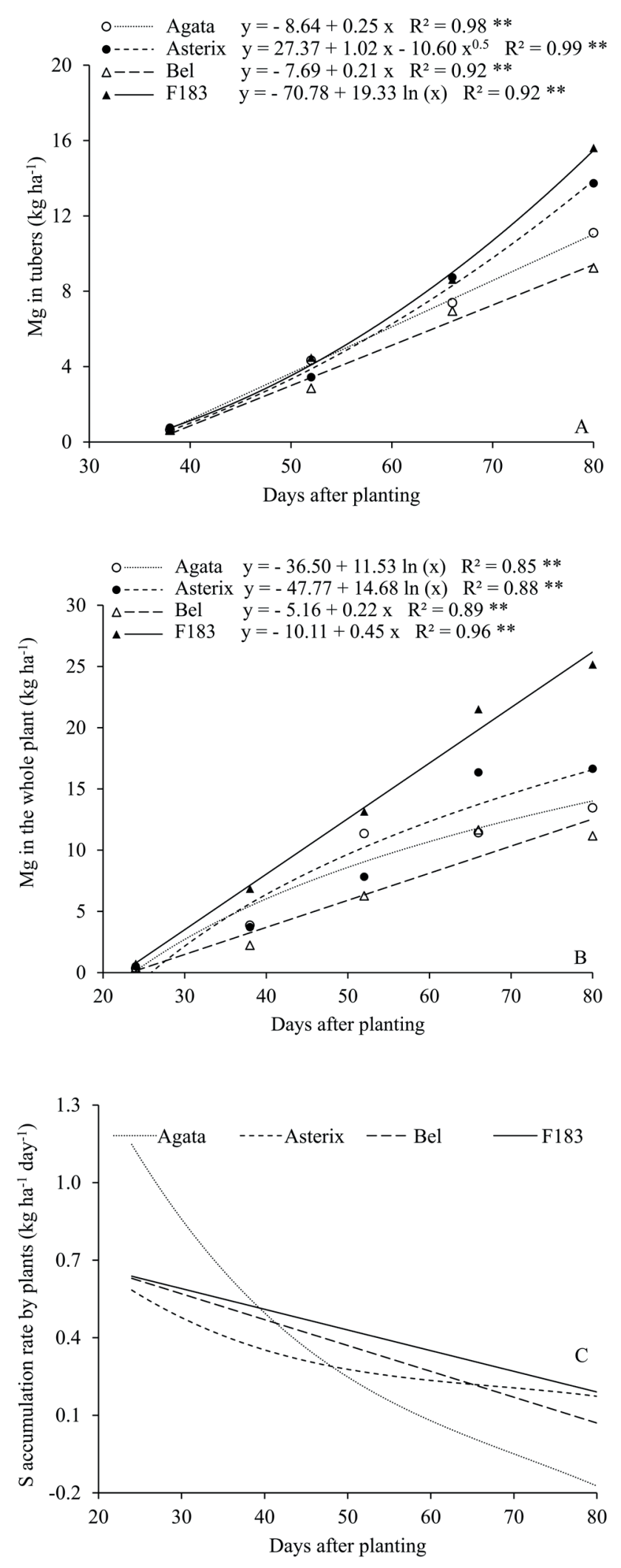

Figure 6. Magnesium (Mg) accumulation in tubers (A) and whole plants (B) and $\mathrm{Mg}$ accumulation rate of plants (C) of three potato genotypes and one elite clone over the production cycle. 
absorption, the amount of nutrient that is required by the plant at a given stage of the cycle should be applied at two weeks before that stage of the cycle (Sancho 1999). In addition, the nutrient losses due to volatilization, leaching and/or immobilization must be considered, and the fertilizer quantities must be adjusted according to these losses. Nutrient losses may also be minimized if fertilization is performed more often in a fractionated manner. Thus, by applying the amount of nutrients required by a genotype at the appropriate time, based on the respective nutrient accumulation rate curves, it is possible to improve the fertilization management.

Nitrogen and $\mathrm{K}$ tend to release faster than P and S (McCaskill \& Blair 1989, Ni et al. 2011, Plotegher \& Ribeiro 2016). Owing to their faster release, reaching $100 \%$ in some days, it becomes feasible to apply fertilizers to minimize losses. Based on the curves obtained in the present study, planting fertilization can be carried out with the amount of $\mathrm{N}$ accumulated from planting up to 24 DAP, equivalent to $10.30,18.17,9.87$ and $11.24 \mathrm{~kg} \mathrm{ha}^{-1}$, respectively for Agata, Asterix, BRSIPR Bel and F183-08-01. Topdressing fertilization could be started from the heap date (24 DAP), at the desired frequency, from the nutrient accumulation rate (Figures 1D, 2C, 3D, 4D, 5D and 6C) obtained from the first derivative of the adjusted $\mathrm{N}$ accumulation equations of whole plants (Figures 1C, 2B, 3C, 4C, 5C and 6B). This idea can also be used for other nutrients, considering the release rate of each nutrient, and associated with other technologies, such as coated fertilizers (Ni et al. 2011).

The nutrient allocation to the tubers was not different among the studied genotypes for any of the macronutrients. The average percentage of nutrient allocation in the tubers among the genotypes presented the following decreasing order: $\mathrm{P}(88 \%)>$ $\mathrm{N}(80 \%)>\mathrm{S}(77 \%)>\operatorname{Mg}(72 \%)>\mathrm{K}(59 \%)>$ $\mathrm{Ca}(12 \%)$. Soratto \& Fernandes (2016) observed a percentage of nutrient allocation in Agata tubers in the order: $\mathrm{P}(84 \%)>\mathrm{N}(82 \%)>\mathrm{K}(79 \%)>$ $\mathrm{S}(67 \%)>\operatorname{Mg}(45 \%)>\mathrm{Ca}(19 \%)$, in which the two most efficient and the least efficient allocated nutrients were similar to those in the present study.

F183-08-01 accumulated the largest amounts of N, P, Ca, S and Mg in whole plants (Figures 1C, 2B, $4 \mathrm{C}, 5 \mathrm{C}$ and $6 \mathrm{~B}$ ) and of dry mass in whole plants at 80 DAP (Table 2). The amounts of dry mass accumulated by all the studied genotypes in whole plants at 80 DAP followed a decreasing order: F183-08-01 > Asterix $>$ BRSIPR Bel $>$ Agata. The amounts of nutrients accumulated in whole plants at this stage followed the same order only for the $\mathrm{N}$ and $\mathrm{Mg}$ nutrients. The other nutrients did not follow the same order, emphasizing the differences among the genotypes, regarding the nutrient uptake.

\section{CONCLUSIONS}

1. The accumulation of macronutrients by whole plants $\left(\mathrm{kg} \mathrm{ha}^{-1}\right)$ followed a descending order: $\mathrm{K}>$ $\mathrm{N}>\mathrm{Ca}>\mathrm{Mg}=\mathrm{S}>\mathrm{P}$;

2. The F183-08-01 genotype showed the highest total accumulation of $\mathrm{N}, \mathrm{Ca}, \mathrm{Mg}$ and $\mathrm{S}$ in plants, being 141.37, 29.21, 25.16 and $22.36 \mathrm{~kg} \mathrm{ha}^{-1}$, respectively;

3. The highest rates of macronutrient accumulation for all the evaluated potato genotypes occurred at 24 days after planting;

4. Side-dressing fertilization should be performed based on the release rate of the fertilizers and the accumulation rate of nutrients for each potato genotype;

5. Nitrogen planting fertilization should be carried out with $10.30,18.17,9.87$ and $11.24 \mathrm{~kg} \mathrm{ha}^{-1}$ for Agata, Asterix, Bel and F183, respectively, and split fertilization based on their respective $\mathrm{N}$ accumulation rates.

\section{ACKNOWLEDGMENTS}

We thank the Empresa Brasileira de Pesquisa Agropecuária (Embrapa) and Coordenação de Aperfeiçoamento de Pessoal de Nível Superior (Capes).

\section{REFERENCES}

AHMED, N. U.; FERDOUS, Z.; MAHMUD, N. U.; HOSSAIN, A.; ZAMAN, M. A. U. Effect of split application of nitrogen fertilizer on the yield and quality of potato (Solanum tuberosum). International Journal of Natural and Social Sciences, v. 4, n. 2, p. 60-66, 2017.

AlvA, A. K.; HODGES, T.; BOYDSTON, R. A.; COLLINS, H. P. Dry matter and nitrogen accumulations and partitioning in two potato cultivars. Journal of Plant Nutrition, v. 25, n. 8, p. 1621-1630, 2002.

ALVA, A.; FAN, M.; QING, C.; ROSEN, C.; REN, H. Improving nutrient-use efficiency in Chinese potato 
production: experiences from the United States. Journal of Crop Improvement, v. 25, n. 1, p. 46-85, 2011.

BRASIL. Instituto Nacional de Meteorologia. Estações Automáticas. Brasília, DF: INMET, 2019.

CENTRODE ESTUDOS AVANÇADOS EMECONOMIA APLICADA (Cepea). Especial batata: gestão sustentável. Hortifruti Brasil, v. 18, n. 194, p. 1-46, 2019.

EMPRESA BRASILEIRA DE PESQUISA AGROPECUÁRIA (Embrapa). Sistema de produção da batata. 2. ed. Brasília, DF: Embrapa, 2016.

ESTEFAN, G.; SOMMER, R.; RYAN, J. Methods of soil, plant, and water analysis: a manual for the west Asia and north Africa region. 3. ed. Beirut: ICARDA, 2013.

FERNANDES, A. M.; SORATTO, R. P.; EVANGELISTA, R. M.; NARDIN, I. Qualidade físicoquímica e de fritura de tubérculos de cultivares de batata na safra de inverno. Horticultura Brasileira, v. 28, n. 3, p. 299-304, 2010a.

FERNANDES, A. M.; SORATTO, R. P.; SILVA, B. L. Extração e exportação de nutrientes em cultivares de batata: I - Macronutrientes. Revista Brasileira de Ciência do Solo, v. 35, n. 6, p. 2039-2056, 2011.

FERNANDES, A. M.; SORATTO, R. P.; SILVA, B. L.; SOUZA-SCHLICK, G. D. Crescimento, acúmulo e distribuição de matéria seca em cultivares de batata na safra de inverno. Pesquisa Agropecuária Brasileira, v. 45, n. 8 , p. $826-835,2010$ b.

FERNANDES, A. M.; SORATTO, R. P.; SOUZA, E. F. C.; JOB, A. L. G. Nutrient uptake and removal by potato cultivars as affected by phosphate fertilization of soils with different levels of phosphorus availability. Revista Brasileira de Ciência do Solo, v. 41, n. 1, p. 1-23, 2017.

INSTITUTO BRASILEIRO DE GEOGRAFIA E ESTATÍSTICA (IBGE). Levantamento sistemático da produção agrícola. 2020. Available at: https://sidra.ibge. gov.br/home/lspa. Access on: Oct. 12, 2020.

MARSCHNER, H. Mineral nutrition of higher plants. 3. ed. San Diego: Academic Press, 2012.

MCCASKILL, M. R.; BLAIR, G. J. A model for the release of sulfur from elemental $\mathrm{S}$ and superphosphate. Fertilizer Research, v. 19, n. 2, p. 77-84, 1989.

NI, B.; LIU, M.; LÜ, S.; XIE, L.; WANG, Y. Environmentally friendly slow-release nitrogen fertilizer. Journal of Agricultural and Food Chemistry, v. 59, n. 18, p. 1016910175, 2011.
PLOTEGHER, F.; RIBEIRO, C. Characterization of single superphosphate powders: a study of milling effects on solubilization kinetics. Materials Research, v. 19, n. 1, p. 98-105, 2016.

R CORE TEAM. $R$ : a language and environment for statistical computing. Viena: R Foundation for statistical computing, 2014.

RENS, L.; ZOTARELLI, L.; ALVA, A.; ROWLAND, D.; LIU, G.; MORGAN, K. Fertilizer nitrogen uptake efficiencies for potato as influenced by application timing. Nutrient Cycling in Agroecosystems, v. 104, n. 2, p. 175185, 2016.

RIBEIRO, A. C.; GUIMARÃES, P. T. G.; ALVAREZ, V. H. Recomendações para o uso de corretivos e fertilizantes em Minas Gerais. 5. ed. Viçosa: SBCS, 1999.

SANCHO, H. Curvas de absorción de nutrientes: importancia y uso en los programas de fertilización. Informaciones Agronomicas, n. 36, p. 11-13, 1999.

SANDAÑA, P. Phosphorus uptake and utilization efficiency in response to potato genotype and phosphorus availability. European Journal of Agronomy, v. 76, n. 1, p. 95-106, 2016.

SILVA, A. L. B. R.; ZOTARELLI, L.; DUKES, M. D.; AGEHARA, S.; ASSENG, S.; SANTEN, E. V. Irrigation method and application timing effect on potato nitrogen fertilizer uptake efficiency. Nutrient Cycling in Agroecosystems, v. 112, n. 2, p. 253-264, 2018.

SILVA, G. O. da; PEREIRA, A. D. S.; BAIL, F. E.; PONIJALEKI, R.; CARVALHO, A. D. F. Resposta de cultivares de batata a níveis crescentes de NPK. Revista Ceres, v. 64, n. 5, p. 492-499, 2017.

SINGH, P.; SINGH, R. K.; SONG, Q. Q.; LI, H. B.; YANG, L. T.; LI, Y. R. Methods for estimation of nitrogen components in plants and microorganisms. In: GUPTA, K. Nitrogen metabolism in plants. New York: Humana, 2020. p. 103-112.

SORATTO, R. P.; FERNANDES, A. M. Phosphorus effects on biomass accumulation and nutrient uptake and removal in two potato cultivars. Soil Fertility \& Crop Nutrition, v. 108, n. 3, p. 1225-1236, 2016.

UNITED STATES DEPARTMENT OF AGRICULTURE (USDA). Soil taxonomy: a basic system of soil classification for making and interpreting soil surveys. 2. ed. Washington, DC: USDA, 1999.

WEBER, M. A.; MIELNICZUK, J. Estoque e disponibilidade de nitrogênio no solo em experimento de longa duração. Revista Brasileira de Ciência do Solo, v. 33, n. 2, p. 429-438, 2009. 